\title{
UPAYA PEMADAMAN KEBAKARAN HUTAN DAN LAHAN MENGGUNAKAN GEL PEMADAM (Gel Pack Extinguishing Agent)
}

\author{
Forest and Land Fires Suppresion Effort Using Gel Pack Extinguishing Agent \\ Bambang Hero Saharjo $^{1^{*}}$ dan Irbah Imtinan ${ }^{1}$
}

(Diterima Februari 2019/Disetujui Maret 2019)

\begin{abstract}
Forest and land fires become serious problems in Indonesia that could not be well managed until today. This is then the reasons why there is so many activties being conducted in order to find the best solution including fire suppression method. Until today the suppresion methods mostly using water rather than other sources, which actually is not so effective and efficient. The research is proposed to make sure that Gel Pack Extinguishing Agent (GPEA) could be used for fire suppression. Three different fuels used were Pinus merkusii, Shorea leprosula, and Dicranopteris linearis at different of $55 \mathrm{~g}, 65 \mathrm{~g}$, $75 \mathrm{~g}$, dan $85 \mathrm{~g}$. The results of research shown that GPEA with 5 small box per litter of water was the best dosage. The fastes suppression time based on the three fuels was Dicranopteris linearis, and the lowest was Pinus merkusii.
\end{abstract}

Key words: fuels, forest and land fires, Gel, suppresion methode, dosage

\section{PENDAHULUAN}

Kebakaran hutan dan lahan adalah salah satu penyebab degradasi dan deforestasi hutan Indonesia. Deforestasi dan degradasi hutan yang terjadi di Indonesia mendorong munculnya isu sebagai penyumbang emisi karbon yang cukup besar.

Di Indonesia, kebakaran hutan telah menjadi masalah serius yang sampai saat ini masih belum dapat diatasi dengan baik, sehingga kebakaran hutan dan lahan telah menjadi ciri khas hutan Indonesia. Kegiatan penyiapan lahan yang tidak benar, pertambahan jumlah penduduk serta kondisi iklim yang tidak menentu merupakan salah satu penyebab tingginya masalah kebakaran hutan dan lahan di Indonesia. Kandungan $\mathrm{CO}_{2}$ di udara meningkat dengan adanya kebakaran hutan dan lahan. Peningkatan $\mathrm{CO}_{2}$ memberikan kontribusi terhadap peningkatan suhu rata-rata dan pemanasan global.

Kebakaran hutan dan lahan pada umumnya sangat merugikan karena menghilangkan kayu dan tegakan hutan yang bernilai ekonomis tinggi. Tacconi (2003) menyatakan bahwa kebakaran hutan di Indonesia pada tahun 1997/1998 telah mencapai kerugian antara US \$2.84

\footnotetext{
${ }^{1}$ Staff Pengajar Dept. Silvikultur, Fakultas Kehutanan IPB

* Penulis korespondensi:

e-mail: bhherosaharjo@gmail.com

${ }^{2}$ Mahasiswa Dept. Silvikultur, Fakultas Kehutanan IPB
}

miliar hingga US \$4.86 miliar. Dampak merugikan lainnya dari kebakaran hutan dan lahan adalah jumlah lahan kritis yang semakin bertambah, kerusakan flora/fauna dan kerugian lain dengan menurunnya kualitas lingkungan. Menurut Rasyid (2014) salah satu dampak kebakaran hutan adalah hilangnya tumbuh-tumbuhan yang menyebabkan lahan menjadi terbuka, sehingga mudah tererosi dan tidak dapat menahan banjir.

Upaya pemadaman kebakaran hutan dan lahan sangat terbatas, saat ini pemadaman kebakaran hutan dan lahan di Indonesia menggunakan air, dimana air yang dijatuhkan dari atas pada suhu yang panas akan menguap ke udara sehingga tidak sampai pada titik kebakaran. Menurut Akbar (2016) proses penurunan suhu bahan bakar tidak terjadi karena air yang diturunkan melalui hujan bisa diuapkan kembali ke udara pada suhu api yang tinggi. Hal ini membuat pemadaman dengan metode tersebut menjadi tidak efektif dan efisien, sehingga dibutuhkan metode pemadaman kebakaran hutan dan lahan yang lebih efektif dan efisien pada aspek sosial, ekonomi serta ekologi.

Penelitian ini bertujuan untuk memastikan gel pemadam yaitu Gel Pack Extinguishing Agent (GPEA) dapat digunakan dalam upaya pemadaman kebakaran hutan dan lahan.GPEA merupakan agen pemadam kebakaran hutan dan lahan yang digunakan sebagai metode baru untuk pemadaman kebakaran hutan dan lahan. GPEA diharapkan dapat membentuk zona pencegahan kebakaran hutan dan lahan yang menyebar. 


\section{METODE PENELITIAN}

\section{Waktu dan Lokasi Penelitian}

Penelitian dilaksanakan pada bulan OktoberDesember 2018 di Laboratorium Kebakaran Hutan dan Lahan Departemen Silvikultur Fakultas Kehutanan Institut Pertanian Bogor. Lokasi pengambilan sampel serasah di sekitar kampus IPB Dramaga Bogor.

\section{Alat dan Bahan}

Alat-alat yang digunakan dalam penelitian ini adalah timbangan digital, oven, penggaris, alat pengukur suhu api, alat pengukur kecepatan angin, kasa, kaki tiga, lampu bunsen, alat perekam video, alat penyemprot berdiameter $0.5 \mathrm{~cm}$, termometer dan alat penghitung waktu. Bahan yang digunakan adalah gel pemadam yaitu Gel Pack Extinguishing Agent (GPEA), air, serasah daun Pinus merkusii, serasah daun Shorea leprosula, serta Dicranopteris linearis.

\section{Prosedur Penelitian}

Pelaksanaan penelitian ini terdiri dari beberapa tahapan yaitu persiapan, pengovenan, pembakaran, pemadaman serta pengamatan. Garis besar diagram alir penelitian ini ditunjukkan oleh Gambar 1.

\section{Persiapan}

Tahap persiapan meliputi persiapan alat berupa oven, timbangan digital, kaki tiga, lampu bunsen, kasa berukuran $17 \mathrm{~cm}$ x $20 \mathrm{~cm}$, alat pengukur suhu, alat pengukur kecepatan angin, penggaris, alat penyemprot berdiameter $0.5 \mathrm{~cm}$ dan bahan berupa serasah daun Pinus merkusii, serasah daun Shorea leprosula, tumbuhan bawah jenis paku Dicranopteris linearis dengan berat yang sama untuk setiap jenis bahan bakar yaitu $55 \mathrm{~g}, 65 \mathrm{~g}$, 75g, dan 85g, GPEA, serta air.

\section{Pengovenan}

Tahap pengovenan meliputi pengovenan bahan bakar berupa serasah daun $P$. merkusii, serasah daun $S$. leprosula, serta tumbuhan bawah jenis paku $D$. linearis yang di oven selama 24 jam dengan suhu $105^{\circ} \mathrm{C}$, yang kemudian ditimbang kembali untuk perhitungan kadar air.

\section{Pembakaran}

Pengujian gel dalam rangka untuk melihat kemampuannya dalam pemadaman kebakaran dimulai

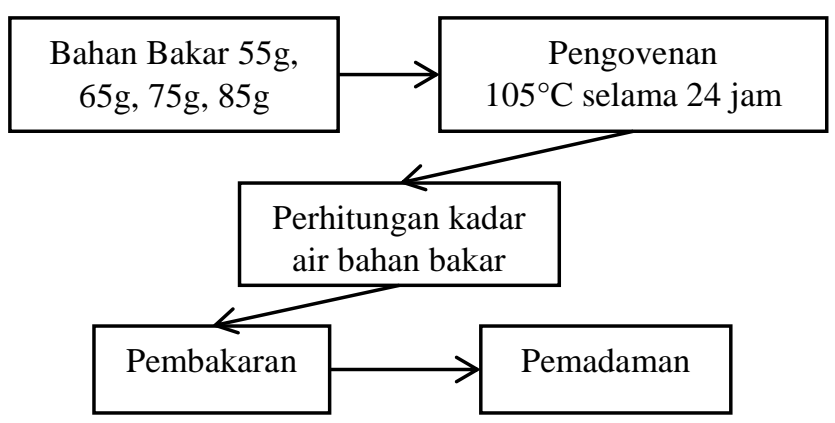

Gambar 1 Diagram alir penelitian dengan pembakaran bahan bakar. Bahan bakar berupa serasah daun P.merkusii, serasah daun S.leprosula, serta tumbuhan bawah jenis paku D.linearis yang akan dibakar telah melalui tahap penimbangan, pengovenan, pengukuran ketebalan bahan bakar, perhitungan kadar air bahan bakar sebelumnya. Data pendukung seperti suhu dan kelembaban di lokasi pembakaran serta perhitungan kecepatan angin dilakukan pada saat proses pembakaran dimulai.

\section{Pemadaman}

Pemadaman dilakukan setelah bahan bakar berupa serasah daun P.merkusii, serasah daun S. leprosula, serta tumbuhan bawah jenis paku D.linearis dibakar yaitu setelah 30 detik dari proses pembakaran dengan jarak 40 $\mathrm{cm}$ serta menggunakan wadah GPEA berdiameter $0.5 \mathrm{~cm}$ dengan dosis GPEA 5 bungkus per liter air.

\section{Pengamatan}

Pengamatan yang meliputi pengukuran waktu pemadaman menggunakann GPEA dengan dosis 5 bungkus per liter air pada tahap pemadaman.

\section{Analisis Data}

Pengolahan dan analisis data yang digunakan yaitu perhitungan kadar air bahan bakar dan analisa sidik ragam:

\section{Kadar air bahan bakar}

$$
\text { Perhitungan } \mathrm{KA}=\frac{B B-B K}{B K} \times 100
$$

Keterangan:

$$
\begin{aligned}
& \mathrm{KA}=\text { Kadar air }(\%) \\
& \mathrm{BB}=\text { Berat basah sebelum dioven }(\mathrm{g}) \\
& \mathrm{BK}=\text { Berat kering setelah dioven }(\mathrm{g})
\end{aligned}
$$

\section{Analisis sidik ragam}

Pengujian dilakukan dengan menggunakan analisis Rancangan Acak Lengkap (RAL) pada lama pemadaman. Analisis yang digunakan merupakan RAL dengan dua faktor yaitu terdiri dari jenis bahan bakar dan berat basah bahan bakar. Perlakuan dari penelitian ini terdiri dari tiga ulangan sehingga terdapat 36 kali satuan percobaan. Model linear yang digunakan adalah sebagai berikut:

$$
Y_{i j}=\mu+\alpha_{i}+\varepsilon_{i j}
$$

Keterangan :

Yij = hasil pengamatan perlakuan ke-i dan ulangan ke-j

$\mu=$ nilai rataan umum

$\alpha_{i}=$ pengaruh faktor lama pemadaman pada taraf ke-i

$\varepsilon_{i j}=$ galat percobaan perlakuan ke-i ulangan ke-j

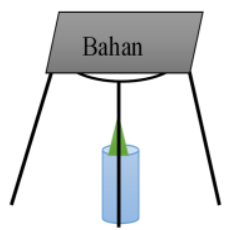

Gambar 2 Ilustrasi proses pembakaran 


\section{HASIL DAN PEMBAHASAN}

Kondisi awal proses pembakaran sebelum pembakaran disajikan pada Tabel 1. Suhu sebelum pembakaran yaitu $28.4^{\circ} \mathrm{C}$, dengan $\mathrm{RH}$ sekitar $65 \%$ pukul 14.00 WIB.

Faktor alami yang memengaruhi kebakaran hutan dan lahan adalah faktor iklim dan cuaca. Menurut Sukmawati (2006), faktor iklim dan cuaca yang memengaruhi kebakaran hutan dan lahan yakni (1) kelembaban udara menentukan kandungan air bahan bakar dan terjadinya kebakaran, (2) suhu udara memengaruhi kekeringan suatu wilayah terutama pada musim kemarau, (3) curah hujan memengaruhi kelembaban dan kandungan air bahan bakar, (4) angin membantu pengeringan bahan bakar dan menentukan arah penjalaran api. Unsur cuaca sangat memengaruhi kebakaran hutan seperti radiasi matahari, waktu memengaruhi terjadinya kebakaran yakni dari pemanasan bahan bakar. Waktu tengah hari akan mencapai suhu yang maksimum sedangkan saat menjelang matahari terbenam akan mencapai suhu minimum (Schroeder dan Buck 1970). Menurut Heikkila et al. (1993), menyatakan bahwa kejadian kebakaran sebanyak $87 \%$ dimulai pada pukul 10.00 hingga pukul 17.00, namun puncak kebakaran pada umumnya yang paling tinggi pada pukul 14.00 dengan jumlah 109 dari 110 kejadian kebakaran.

Suhu udara merupakan faktor yang penting dalam terjadinya kebakaran. Suhu udara merupakan faktor yang

Tabel 1 Kondisi awal sebelum pembakaran

\begin{tabular}{ccc}
\hline $\begin{array}{c}\text { Waktu pembakaran } \\
\text { (WIB) }\end{array}$ & Suhu ruang $\left({ }^{\circ} \mathrm{C}\right)$ & RH (\%) \\
\hline 14.00 & 28.4 & 65 \\
\hline
\end{tabular}

Tabel 2 Kadar air bahan bakar

\begin{tabular}{lcccc}
\hline $\begin{array}{c}\text { Jenis Bahan } \\
\text { Bakar }\end{array}$ & $\begin{array}{c}\text { BB } \\
(\mathrm{g})\end{array}$ & $\begin{array}{c}\text { Ketebalan } \\
\text { bahan bakar } \\
(\mathrm{cm})\end{array}$ & $\begin{array}{c}\text { BK } \\
(\mathrm{g})\end{array}$ & $\begin{array}{c}\text { KA } \\
(\%)\end{array}$ \\
\hline $\begin{array}{l}\text { Serasah } \\
\text { daun }\end{array}$ & 55 & 5.83 & 45 & 22.22 \\
Shorea & 65 & 7.67 & 56 & 16.07 \\
leprosula & 75 & 6.67 & 56 & 33.93 \\
& 85 & 6.17 & 69 & 23.19 \\
\hline & 55 & 4.00 & 40 & 37.5 \\
Serasah daun & 65 & 4.67 & 47 & 38.3 \\
Pinus merkusii & 75 & 4.33 & 55 & 36.36 \\
& 85 & 5.33 & 60 & 41.67 \\
\hline & 55 & 5 & 21 & 161.9 \\
Dicranopteris & 65 & 6.17 & 25 & 160 \\
linearis & 75 & 4.67 & 28 & 167.9 \\
& 85 & 5.67 & 32 & 165.6 \\
\hline
\end{tabular}

Keterangan : $\mathrm{BB}=$ berat basah; $\mathrm{BK}=$ berat Kering; $\mathrm{KA}=$ kadar air berpengaruh pada suhu bahan bakar dan kemudahan bahan bakar untuk terbakar (Young dan Giese 1991). Pagi hari dengan suhu yang rendah sekitar $20^{\circ} \mathrm{C}$ ditambah dengan kecepatan angin yang rendah membuat api tidak berkembang sehingga terkonsentrasi pada satu titik. Siang hari dengan suhu $30-35^{\circ} \mathrm{C}$ dengan kadar air bahan bakar cukup rendah $(<30 \%)$ akan membuat proses pembakaran berlangsung dengan cepat dan tidak pada satu

\section{Kadar air bahan bakar}

Kadar air bahan bakar memengaruhi terjadinya proses pembakaran. Oleh karena itu diperlukan pengukuran kadar air bahan bakar untuk mengetahui kerentanan suatu bahan bakar terhadap kebakaran. Kadar air bahan bakar disajikan pada Tabel 2.

Tabel 2 menunjukkan kadar air dari setiap jenis bahan bakar yang berbeda yang digunakan. Perbedaan kadar air yang terlihat sangat berbeda terdapat pada jenis bahan bakar tumbuhan bawah D.linearis yakni termasuk kadar air bahan bakar yang sangat tinggi yakni $>160 \%$ dari setiap berat basah yang digunakan dalam penelitian, hal ini dikarenakan bahan bakar tumbuhan bawah yang digunakan merupakan bahan bakar hidup bukan bahan bakar mati seperti jenis S.leprosula dan P.merkusii yang digunakan. Menurut Akbar (2016) vegetasi hidup mengandung kira-kira $80 \%$ air dari beratnya. Perbedaan ketebalan bahan bakar yang ditunjukkan pada tabel 2 terlihat mengikuti berat basah yang digunakan, yakni semakin berat maka ketebalan yang ditunjukkan semakin tebal. Berat kering pada jenis bahan bakar tumbuhan bawah D.linearis jauh berbeda dengan berat basahn. Hal ini akan berpengaruh pada perilaku api, dikarenakan ketersediaan bahan bakar yang menurun.

Gambar 3 menunjukkan garis perbedaan masingmasing jenis bahan bakar dengan beratnya. Jenis bahan bakar serasah daun S.leprosula memiliki kadar air yang lebih rendah dari 2 jenis bahan bakar yang lain, namun berdasarkan klasifikasinya kadar air bahan bakar $(<30 \%)$
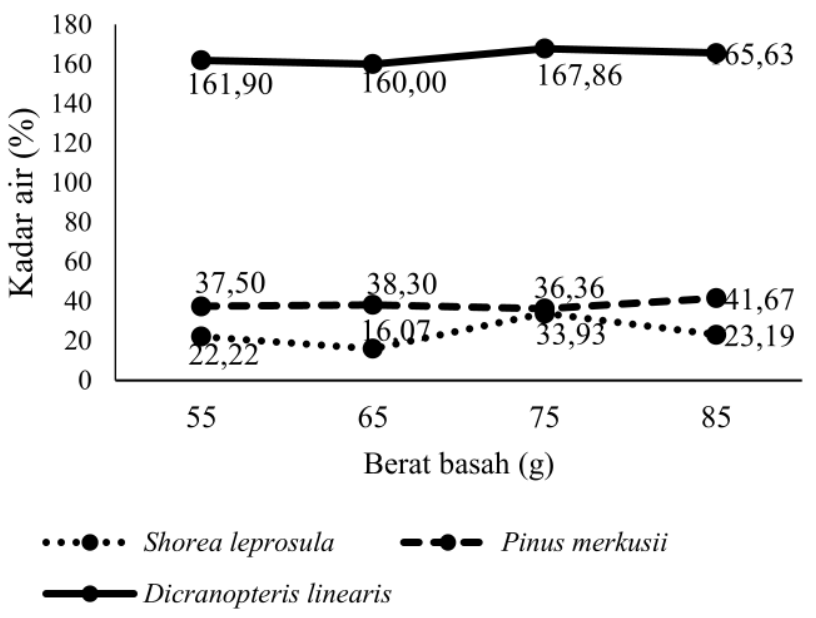

Gambar 3 Kadar air bahan bakar 
rentan terbakar (Heikkila et al. 1993). Kadar air bahan bakar serasah daun S.leprosula bervariasi berkisar dari 20$34 \%$ hal ini menunjukkan kerentanan terhadap proses pembakaran. Kadar air bahan bakar tertinggi ada pada jenis tumbuhan bawah D.linearis yakni $>160 \%$, hal ini dikarenakan jenis bahan bakar tersebut merupakan bahan bakar hidup yang belum mengalami proses pengeringan dari penyinaran matahari. Aryanti (2002) menyatakan bahwa keadaan kandungan air bahan bakar sangat dipengaruhi oleh temperatur, lama penyinaran matahari, kelembaban udara, curah hujan terakhir, kadar air tanah, jenis vegetasi serta topografi. Kadar air bahan bakar sangat memengaruhi penyalaan api, proses pembakaran, dan intensitas api. Bahan bakar tumbuhan bawah jenis D.linearis berdasarkan perhitungan kadar air mengandung air yang cukup banyak, sehingga pada jenis bahan bakar tumbuhan bawah ini tidak rentan terbakar. Hal ini berkaitan dengan penguapan air selama proses pembakaran. Semakin tinggi kadar air bahan bakar, maka semakin banyak energi panas yang diperlukan untuk menguapkan air didalam bahan bakar untuk mencapai fase titik bakar. Oleh karena itu bahan bakar yang memiliki kadar air lebih redah akan lebih mudah terbakar dan api dari proses pembakaran akan menjalar lebih cepat (Akbar 2016).

\section{Kecepatan angin dan lama penyulutan}

Kecepatan angin mampu memengaruhi lama penyulutan. Kecepatan angin dan lama penyulutan disajikan pada Gambar 4. Gambar 4 menunjukkan adanya hubungan antara kecepatan angin dan lama penyulutan, ketika kecepatan angin $0 \mathrm{mps}$ lama penyulutan cenderung berlangsung cepat. Jenis bahan bakar serasah daun S.leprosula dengan berat $85 \mathrm{~g}$ menunjukkan lama peyulutan yang cenderung lambat, hal ini dikarenakan volume dan kepadatan bahan bakar yang cukup besar disertai dengan adanya pengaruh angin yang cenderung tidak konsisten sehingga lama penyalaan berlangsung lambat. Jenis bahan bakar serasah daun $P$. merkusii lama penyulutan berlangsung lebih cepat dari jenis bahan bakar yang lain. Hal ini dikarenakan luas permukaan daun $P$. merkusii yang menyeluruh pada bagian daun membuat daun sangat mudah terbakar, selain itu daun P. merkusii

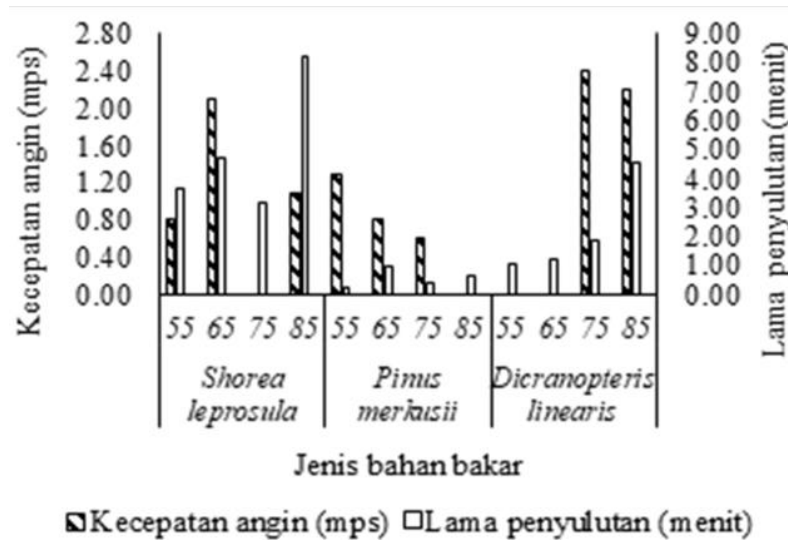

Gambar 4 Kecepatan angin dan lama penyulutan mengandung zat ekstraktif yang mudah terbakar. Jenis bahan bakar yang berasal dari tumbuhan berdaun jarum umumya lebih mudah terbakar daripada tumbuhan berdaun lebar, hal ini dikarenakan pada tumbuhan berdaun jarum lebih banyak mengandung resin (zat ekstraktif) sehingga mudah terbakar. Sementara pada tumbuhan berdaun lebar biasanya memiliki zat ekstraktif yang meyebabkan tumbuhan tersebut sulit terbakar (Clar dan Chatten 1954). Menurut Aswin (2005), jenis Shorea spp. ialah salah satu jenis tumbuhan yang memiliki proses penyalaan cenderung rendah daripada jenis lainnya. Jenis tumbuhan bawah D.linearis lama penyalaan cenderung meningkat mengikuti berat bahan bakar yang berbeda, selain itu ketika kecepatan angin $0 \mathrm{mps}$ lama penyalaan cenderung seragam dengan dua berat bakar yang berbeda.

\section{Ketebalan bahan bakar dan tinggi api}

Ketebalan bahan bakar mampu memengaruhi tinggi api yang dihasilkan. Ketebalan bahan bakar dan tinggi api disajikan pada Gambar 5. Gambar 5 menunjukkan adanya hubungan antar ketebalan bahan bakar dan tinggi api. Jenis serasah daun P.merkusii memiliki ketebalan bahan bakar dan tinggi api berbanding lurus, namun pada jenis serasah daun S.leprosula dan tumbuhan bawah D.linearis menunjukkan garis yang berbeda, yakni adanya penurunan garis di salah satu ketebalan bahan bakar. Hal ini dikarenakan jenis serasah daun S.leprosula mempunyai susunan yang berbeda dari kedua jenis bahan bakar yang berbeda dari kedua jenis bahan bakar yang digunakan, selain itu jenis bahan bakar berdaun lebar lebih sukar terbakar dikarenakan adanya zat ekstraktif yang menyebabkan tumbuhan berdaun lebar sukar terbakar (Clar dan Chatten 1954). Brown dan Davis (1973) menyatakan bahwa ketebalan bahan bakar berhubungan erat dengan susunan bahan bakar, hal inilah yang membuat adanya variasi tinggi api dari berbagai jenis bahan bakar yang digunakan. Susunan bahan bakar merupakan faktor utama dalam perilaku api, karena transfer panas yang dihasilkan dengan radiasi, konduksi maupun konveksi berhubungan dengan variabel jarak bahan bakar. Dilihat dari Gambar 4 jenis serasah daun S.leprosula dengan berat basah $85 \mathrm{~g}$ memiliki kecepatan angin yang cenderung besar dan lama

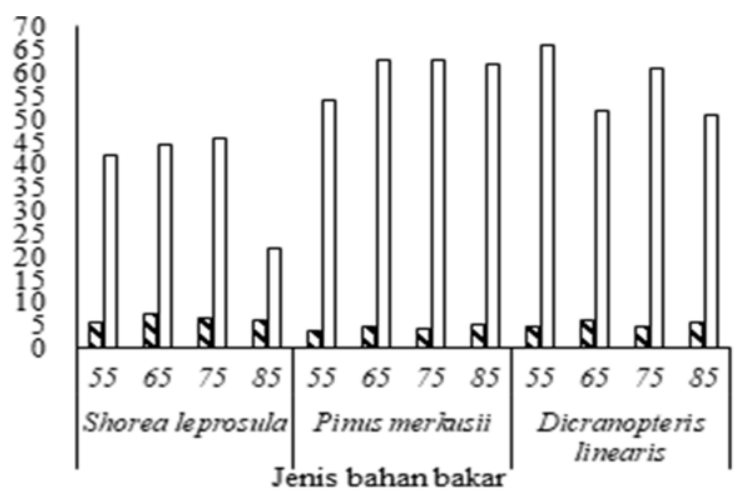

$\Delta$ Ketebalan bahan bakar (cm) $\square$ Tinggi api (cm)

Gambar 5 Ketebalan bahan bakar dan tinggi api 
penyulutan cukup lama yang cukup memengaruhi tinggi api. Perilaku api dapat diperoleh pada saat proses pembakaran yang merupakan suatu reaksi api terhadap lingkungannya seperti keadaan bahan bakar yang tersedia untuk terbakar (muatan bahan bakar, ketebalan bahan bakar, kadar air bahan bakar), iklim, kondisi cuaca lokal (suhu udara, kelembaban udara, kecepatan angin) dan topografi (Donna 2006).

\section{Lama pemadaman dan suhu api}

Hasil analisis RAL terhadap pengaruh jenis bahan bakar dan lama pemadaman menggunakan GPEA disajikan pada Tabel 3 .

Berdasarkan hasil analisis sidik ragam jenis bahan bakar berpengaruh nyata pada lama pemadaman menggunakan GPEA, namun perbedaan perlakuan yaitu pada berat basah tidak berpengaruh nyata pada lama pemadaman. Berdasarkan Tabel 3 menunjukkan bahwa jenis bahan bakar serasah daun P.merkusii dan tumbuhan bawah D.linearis mempunyai perbedaan yang signifikan terhadap lamanya pemadaman berdasarkan uji Tukey dengan taraf $0.05 \%$. Serasah daun S.leprosula menunjukkan tidak mempunyai perbedaan yang signifikan terhadap lamanya pemadaman pada taraf $0.05 \%$.

Gambar 6 menunjukkan hasil pengujian terkait suhu api dan lama pemadaman. Suhu api bahan bakar serasah daun S.leprosula menunjukkan suhu yang paling rendah dari kedua jenis bahan bakar yang digunakan, hal ini terlihat suhu serasah daun S.leprosula berkisar 245.3$532.4^{\circ} \mathrm{C}$ sedangkan suhu jenis bahan bakar serasah daun

Tabel 3 Hasil analisis pengaruh jenis bahan bakar dan lama pemadaman

\begin{tabular}{|c|c|c|}
\hline Jenis bahan bakar & Jumlah & Hasil \\
\hline $\begin{array}{l}\text { Serasah daun } \\
\text { Pinus merkusii }\end{array}$ & 12 & $1.02^{\alpha}$ \\
\hline $\begin{array}{l}\text { Serasah daun } \\
\text { Shorea leprosula }\end{array}$ & 12 & $0.79^{\alpha b}$ \\
\hline $\begin{array}{l}\text { Tumbuhan bawah } \\
\text { Dicranopteris linearis }\end{array}$ & 12 & $0.60^{b}$ \\
\hline
\end{tabular}

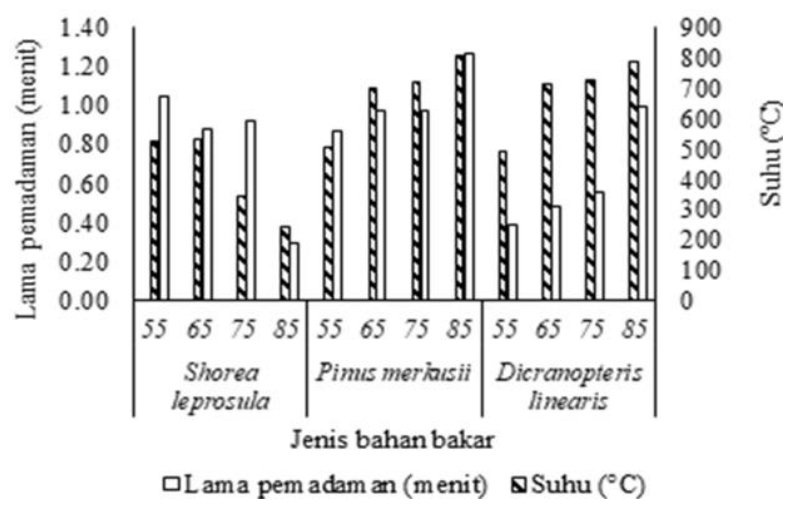

Gambar 6 Lama pemadaman dan suhu api
P.merkusii berkisar $507-812.2^{\circ} \mathrm{C}$ dan suhu bahan bakar jenis tumbuhan bawah D.linearis berkisar $492.9-789.3^{\circ} \mathrm{C}$. Perbedaan suhu terjadi sesuai dengan kandungan berat basah yang berbeda, berat basah yang paling berat menghasilkan suhu api yang paling tinggi. Hal ini berbeda dengan jenis bahan bakar serasah daun S.leprosula yang perbedaan suhu api terjadi pada berat basah yang paling berat yakni menghasilkan suhu terendah pada pengujian terhadap suhu. Hal ini dikarenakan bersangkutan dengan volume bahan bakar dan kandungan didalamnya yang berkaitan dengan suhu yang dihasilkan dan laju pemadamannya (Clar dan Chatten 1954). Dilihat dari Gambar 6 waktu pemadaman berlangsung cepat yaitu berkisar 0.3-1.27 menit hal ini menunjukkan kecepatan pemadaman dari penetrasi ketika dijatuhkannya GPEA. Menurut JICA (2016) penetrasi pemadaman secara konvensional menggunakan air membutuhkan waktu 100 detik untuk meresap, hal ini menunjukkan bahwa waktu yang digunakan untuk pemadaman menggunakan air lebih banyak dibandingkan dengan waktu pemadaman menggunakan GPEA. Lama pemadaman yang paling lama ada pada jenis serasah daun P.merkusii dengan suhu tertinggi diantara kedua jenis bahan bakar yang digunakan. Hal ini dikarenakan zat ekstraktif berupa resin, dan susunan bahan bakar serasah daun P.merkusii sehingga menyebabkan api yang dihasilkan cukup besar, temperatur tinggi dan lamanya pemadaman. Menurut Clar and Chatten (1954), tumbuhan berdaun jarum lebih banyak mengandung resin (zat ekstraktif) sehingga mudah terbakar. Susunan bahan bakar serasah daun P.merkusii dan tumbuhan bawah D.linearis yang jarang membuat kondisi oksigen melimpah sehingga menimbulkan nyala api yang besar (Akbar 2016). Lama pemadaman bergantung pada besarnya api yang dihasilkan dan jenis bahan bakar, namun tidak menunjukkan adanya variasi yang cukup signifikan. Waktu pemadaman yang berlangsung paling cepat terjadi pada jenis bahan bakar tumbuhan bawah D.linearis, hal ini dikarenakan jenis bahan bakar ini mengandung air yang cukup banyak sehingga dalam kondisi yang kering api dengan cepat menjalar dan menghabiskan bahan bakar. Waktu pemadaman berlangsung cepat, hal ini menunjukkan bahwa GPEA dengan dosis 5 bungkus per liter air mampu digunakan sebagai alat pemadaman dari hasil uji yang dilakukan terhadap ketiga jenis bahan bakar.

\section{SIMPULAN DAN SARAN}

\section{Simpulan}

Berdasarkan hasil penelitian pengujian terhadap dosis GPEA sebagai alat bantu pemadaman kebakaran hutan dan lahan dari ketiga jenis bahan bakar yang digunakan yakni serasah daun Pinus merkusii, serasah daun Shorea leprosula, serta tumbuhan bawah jenis paku Dicranopteris linearis dengan berat yang berbeda setiap jenisnya, menunjukkan bahwa GPEA dengan dosis 5 
bungkus per liter air cukup efektif dan efisien digunakan sebagai alat pemadaman kebakaran hutan dan lahan. Waktu pemadaman yang berlangsung paling cepat yakni pada tumbuhan bawah Dicranopteris linearis dengan berat $55 \mathrm{~g}$ pada suhu $492.9^{\circ} \mathrm{C}$ Waktu pemadaman yang berlangsung paling lama yakni pada jenis bahan bakar serasah daun Pinus merkusii dengan berat $85 \mathrm{~g}$ pada suhu $812.2^{\circ} \mathrm{C}$. Jenis bahan bakar serasah daun Shorea leprosula menunjukkan waktu pemadaman diantara kedua jenis bahan bakar lainnya, tidak berlangsung cepat dan tidak berlangsung lama.

\section{Saran}

Saran yang diberikan dari penelitian ini yaitu perlu dilakukan pengujian dengan lebih mendalam terkait hubungan jenis bahan bakar dan waktu pemadaman, selain itu untuk mengetahui efektivitas pemadaman kebakaran hutan dan lahan perlu dilakukan penelitian lebih lanjut mengenai pengaruh perbedaan dosis GPEA agar diperoleh hasil yang optimal, kemudian perlu dilakukan penelitian lebih lanjut dalam skala yang lebih besar untuk pengujian GPEA, serta perlu adanya penelitian perbandingan antara pemadaman menggunakan air dan GPEA.

\section{DAFTAR PUSTAKA}

Akbar A. 2016. Pemahaman dan Solusi Masalah Kebakaran Hutan di Indonesia. Bogor (ID) : Forda Press.

Aryanti E. 2002. Karakteristik kebakaran limbah vegetasi hutan rawa gambut di Desa Pelalawan Propinsi Riau [tesis]. Bogor (ID) : Sekolah Pasca Sarjana Institut Pertanian Bogor.

Aswin U. 2005. Fire Characteristic of Tropical Peat in Central Kalimantan Indonesia [disertasi]. Division of Geoscience Graduate School of Environmental Earth Science. Japan (JP) : Hokkaido University.

Brown AA, Davis KP. 1973. Forest Fire Control and Use. New York (US): McGraw Hill Company.

Clar CR, Chatten LR. 1954. Principles of Forest Fire Management. California (US): Department of Natural Resources Division of Forestry.

Donna R. 2006. Perilaku api dan dampak pembakaran terhadap fauna tanah pada areal penyiapan lahan di hutan sekunder Haurbentes, Jasinga Jawa Barat [skripsi]. Bogor (ID) : Institut Pertanian Bogor.

Fuller M. 1991. Forest Fire An Introduction to Wildland Fire Behavior, Management, Fire Fighting and Prevention. Canada (CA) : Jhon Wiley and Sons. Inc.

[JICA] Japan International Coorporation Agency. 2016. The JICA Partnership Program for Enhancing FireFighting Techniques against Peat-Land and Forest Fires in Balikpapan, Indonesia. Japan (JP) : [FAIS] Kitakyushu Foundation for the Advancement of Industry, Science and Technology.
Heikkila TV, Gronovist R, Jurvelius M. 1993. Handbook on Forest Fire Control. A guide for trainers. Helsinki (FI) : Finnida.

Rachmawati N. 2008. Karakteristik bahan bakar dan perilaku api pada kebakaran hutan dan lahan rawa gambut. Jurnal Hutan Tropis Borneo (22) : 55-64.

Rasyid F. 2014. Permasalahan dan dampak kebakaran hutan. Jurnal Lingkar Widyaiswara 1(4) : 47-59.

Saharjo BH. 1997. Mengapa Hutan dan Lahan Terbakar. Harian Republika 29 September 1997.

Schroeder MJ, Buck CC. 1970. Fire weather. A guide for aplication of meteorological information to forest fire control operations. USDA Forest Service, Agricultural Handbook 360. Washington DC (US) : US Government Printing Office.

Sukmawati A. 2006. Hubungan antara curah hujan dengan titik panas (hotspot) sebagai indikator terjadinnya kebakaran hutan dan lahan di Kabupaten Pontianak Provinsi Kalimantan Barat [skripsi]. Bogor (ID) : Institut Pertanian Bogor.

Sumantri. 2003. Metode Pencegahan Kebakaran Hutan. Pengetahuan Dasar Pengendalian Kebakaran Hutan. Bogor (ID): Fakultas Kehutanan IPB.

Suratmo FG, Husaeni EA, Jaya NS. 2003. Pengetahuan Dasar Pengendalian Kebakaran Hutan. Bogor (ID) : Fakultas Kehutanan Institut Pertanian Bogor.

Suwarsono, Yulianto F, Parwati, Suprapto T. 2009. Pemanfaatan data modis untuk identifikasi daerah bekas terbakar (burned area) berdasarkan perubahan nilai NDVI di Provinsi Kalimantan Tengah tahun 2009. Jurnal Penginderaan Jauh 6(1) : 54-64.

Syaufina L. 2008. Kebakaran Hutan dan Lahan di Indonesia, Perilaku Api, Penyebab dan Dampak Kebakaran. Malang (ID) : Bayumedia Publishing.

Tacconi L. 2003. Kebakaran Hutan di Indonesia : Penyebab, Biaya dan Implikasi Kebijakan. Bogor (ID): Center for International Forestry Research (CIFOR).

Wardhana A. 2003. Penyusunan peringkat bahaya kebakaran hutan berdasarkan indeks kekeringan ketch-byram (ketch-byram drought index/kbdi) dan kode kekeringan (drought code/dc) di Propinsi Riau [skripsi]. Bogor (ID) : Institut Pertanian Bogor.

Young R, Giese R. 1991. Introduction to Forest Fire. Canada (CA) : John Wiley and Sons. Inc. 